\title{
Analysis of the needs of problem children towards the quality of life that is moral and characterized
}

\author{
Hadiwinarto $^{1^{*}}$, Herman Nirwana ${ }^{2}$ \\ ${ }^{1}$ Universitas Bengkulu, ${ }^{2}$ Universitas Negeri Padang \\ *Corresponding author, e-mail: hadiwin@unib.ac.id
}

\begin{abstract}
This study aims to describe problem children, with a sample of 52 child convicts. In-depth interview techniques with counseling approaches, focused discussions and questionnaires were used for data collection. Data analysis used content analysis techniques and descriptive analysis. This research is the result of the first year of research planned for three years. The results of the study show that: child convicts are in a critical age, a period of seeking identity; have a low education background; very rarely interact socially with their father and mother; Child convicts have various unmet needs in their families. Their needs include: psychological needs, physical needs, social needs, future needs, information needs, and the need to live in character and culture. It is recommended that the results of the first year research be used to determine the right education model for child convicts to lead a moral and characterized life.
\end{abstract}

Keywords: the need for juvenile convicts, moral life and character.

How to Cite: Hadiwinarto, H., Nirwana, N. (2019). Analysis of the needs of problem children towards the quality of life that is moral and characterized. International Journal of Research in Counseling and Education, 3 (2) pp. 67-75, DOI: 10.24036/0074za0002

This is an open access article distributed under the Creative Commons 4.0 Attribution License, which permits unrestricted use, distribution, and reproduction in any medium, provided the original work is properly cited. @2019 by author and Universitas Negeri Padang.

\section{Introduction}

The social conditions of the past have been very worrying on almost all sides of life. These conditions reflect a decline in social, cultural and humanitarian values. Slowly but surely one day it will reduce the dignity of the nation, if it is not as soon as possible to do constructive and sustainable social movements. Almost every day electro media and print media broadcast news that indicates a decline in human values, such as: news about murder, theft, rape, sexual harassment, and other criminal acts. This condition illustrates the decline in the application of moral values and character of the Indonesian people in social life.

Field facts in several schools show that there are problem children, such as: personal problems, sociocultural problems, sexual harassment, violence, rape, and even murder that lead to student dismissal. Prisons contain problem children (cases of theft, rape, sexual abuse and murder). They can be categorized as a group of social-problematic children. This fact indicates that problem children do not receive educational services appropriately. For example: the case of rape and murder of junior high school students, known as the "Yuyun case" in the majority of Bengkulu Province's Rejang Lebong regency was carried out by children aged less than 18 years, a 16-year-old teenager dropped out of school because he was proven to fuck his girlfriend age of 16 years (Newpaper Rakyat Bengkulu, 25 Mei 2016)

Indonesia as a country that has ratified the Convention on the Rights of the Child, has an obligation to realize a system of continuous protection of children, so that efforts to fulfill children's basic rights can be carried out to the fullest (Nomor, 11AD). Noting the legislation and the facts in the field, it is necessary to find the best solution. The Indonesian Family Planning Association in the Bengkulu Region as a non-governmental organization since 2014 accompanied the children in dealing with the law that was built by the Correctional Institution. While accompanying the assisted citizens, the fact is that: children with social, cultural and legal problems do not get basic rights properly; there is no policy that allows the availability of basic service facilities; absence of budget support and facilities for basic services; low local government support; there is no regional policy for child services; handling problem children is still sectoral and partial; the community is 
still negative about former child prisoners; the level of public acceptance of former convicts is still very low; the paradigm is still thick, thinking that child convicts are perpetrators, not victims.

In accordance with the phase of human development, adolescents need character education or character right without exception where they are. Ethical education is integrated into all subjects, so students are able to control the emergence of negative behaviors (Murtadlo, 2009). Learning achievements in English, Mathematics, Physics, Chemistry, Biology, History and Geography subjects, each of which does not have a significant positive correlation with character (Hadiwinarto, 2018). This reflects that the learning process in the formal education pathway does not emphasize non-academic aspects in the form of moral values and national character.

Based on the social conditions, it is necessary to do research and development seriously regarding the analysis of the needs of children with problems in a comprehensive manner. The analysis of the needs of social-problematic children is very urgent. The results of the needs analysis can be used as a basis for determining the educational model for them in order to lead a quality of life that is moral and characterized. The education model for social-problematic children is very beneficial for the government and the private sector on a local and national scale. All institutions that handle problem children become very helpful in carrying out their main tasks and functions if there are already available educational models and devices.

Since 2010 the issue of national character education in Indonesia has again become a hot topic in almost all lines of life. Movements to build the culture and character of the nation were proclaimed by the government which began with the 'Declaration of Culture and Nation Character Education' as a national movement in January 2010. These movements were reaffirmed by the president during a speech on National Education Day, May 2, 2010. The declaration appeared can be a reaction of the government to the conditions of social life which shows a decline in the values of national character which is characterized by the increasingly vibrant aggressive behavior that is not only among children and adolescents, but also among adults. Until now, the emergence of certain behaviors that are still a social problem is still ongoing in 2018. Therefore, character education is very important to be instilled in the younger generation, of course by using appropriate, practical, comprehensive and sustainable ways and approaches.

Children with problems with various forms of negative behavior can be categorized as socially pathological behavior. Social pathology as all behaviors that are in conflict with the norms of goodness, local stability, patterns of simplicity, morals, property rights, family solidarity, living in harmony with neighbors, discipline, kindness, and formal law. Social pathology is a symptom where there is no correspondence between the various elements of a whole so that it can endanger the life of the group or that hinder the satisfaction of the fundamental desires of its members, consequently social engagement is completely broken (Kartono, 2011). People in general do not like deviant actions, so they try to deal with and overcome these social problems. Latent social problems are social problems that actually exist, even though they are not yet widespread, but by a group of people covered up and considered non-existent. This social problem will at times emerge as a manifest social problem. For example the problem of social conflict caused by ethnicity, race, religion, and between groups, freedom of sex in religious circles and terrorism. Social problems are a discrepancy between elements of culture or society that endanger social groups (Soekanto, 2012).

The concept of problem children is identical to teenagers. Adolescence is a crucial period for individual development, because at this time individuals experience a biological, cognitive and social transition (Rahmaningsih \& Martani, 2014) . Juvenile delinquency itself is an act of violating legal norms and social norms. According to Moedikdo (2011) juvenile delinquency is all deeds that from adults constitute a crime, for children it is delinquency to be prohibited by law, such as stealing, persecuting and so on. The forms of social problems include: social disorganization, social disintegration, social maladjustment, sociopathic, and abnormal. The form of socially deviant behavior is generally caused by genetic factors, hereditary inheritance which shows a tendency to develop in a pathological direction, and inheritance in a weak constitutional form. Explaining social problems can be through three approaches, namely: psychological approaches, psychological approaches, and sociological approaches (Kartono, 2011).

One of the main causes of the emergence of social problems in the form of poverty can then be caused by the fulfillment of life necessities. That is, if a member of the community fails to meet his life needs, he will tend to commit acts of crime and violence such as stealing, gambling, drunkenness and so on. Character education must be an integral part of education over generations. Education is a humanitarian problem that must be approached from human development itself (Kartadinata, 2013). The concept of a holistic approach and various efforts made by educational institutions, need to be believed that the process of character education must be carried out continually, so that the moral values that have been embedded in the child's personality do not only reach a certain level of education or only appear in the family environment (Suyatno, n.d.). The Ministry of National Education has determined 18 character values that need to be instilled in students sourced from Religion, Pancasila, Culture, and National Education Objectives, namely: religious, 
honest, tolerance, discipline, hard work, creative, independent, democratic, curiosity, enthusiasm nationality, love for the country, respect for achievement, friendship / communicative, peace of mind, love to read, care for the environment, social care, and responsibility (Suyadi, 2013). The existence of cases of child character seems to educators in schools prefer the priority of developing academic aspects, compared to aspects of character.

Children have problems that can be started from mental disability conditions, such as: stress, depression, frustration, personal disorganization, social disorganization and so on. They are generally less accepted by the surrounding community. In this context, it means that there are also problems with the family and the community. Building a child's character is a unique job, because there is no single human child in this world that is exactly the same. Human civilization from time to time is always changing, it can be good, but it can also be bad. The application of a character education model is a process of forming behavior, through at one time, not necessarily right and suitable in other times; there are two types of behavior, namely natural behavior and behavior that are formed through the learning process (Walgito, 2000).

The most appropriate and good model is a model that combines the needs of children, parents, and the surrounding social environment. Government policy in development and its implementation must be based on an analysis of community needs, not the needs of government officials. Instill character education in problem children, there is no other way except through formal, informal, informal education. Proposes that one of the ways to build human beings with character and morality is by building synergy between the school, family, society and government (Hamid \& Sudira, 2013). Public policy cannot be implemented if there is no synergy between the parties concerned. Although schools have implemented character and moral education in the learning environment, this will not be effective if it is not supported by the involvement of families, communities and the government. In line with Ghazali's opinion, the model that forms the character and morals of a child is problematic as if it uses two ways, namely: (1) alloplaties, meaning that the child must change his or her attitude to suit the situation and condition; (2) autoplasties, meaning that the social environment conditions of the community must also be improved in order to understand the issue of moral education and character, understand and accept children in any condition.

\section{Method}

This study uses an expo facto research design that seeks to describe the facts of the field regarding the needs of problem children and their families and the government's commitment to juvenile convicts. This article contains the results of the first phase of the three stages of research. The subjects of this study were children who were assisted by the Special Guidance Institute for Children of the City of Bengkulu and Lapas Curup, Rejang Lebong Regency and their parents. Data collection uses participatory action research that is open and flexible, with in-depth interview techniques individually, focus group discussion, checklist, questionnaire, observation and documentation. Data analysis was performed using quantitative non parametric descriptive statistical approach. The most important thing in data analysis is that valid data and the results of analysis that are more qualitative in nature can be logically understood and accepted by the parties concerned. The validity of the results of the analysis is carried out through participatory coordination meetings.

\section{Results}

Many troubled children are experienced by those aged 14 to 17 years, namely as many as $77 \%$, which is often referred to as age critical of negative things. about $61 \%$ of those with the highest education did not graduate from junior high school. Those who lived with their parents were $71 \%$, but due to various limitations of social interaction in poor families. Problem children come from education-level fathers who have finished high school at the highest level, while around $62 \%$ of mothers have the highest education graduating from junior high school. $58 \%$ of their fathers do not have a steady income, as is their mother's work.

The analysis of the needs of children who are not fulfilled by the family and the environment is described as follows: as many as $81 \%$ of problem children have 13 to 15 types of needs from 15 types of psychological needs. Psychological needs include: affection, appreciation, certain positions in the family, recognition in family, protection, comfort, sense of belonging to the family, sense of togetherness in the family, discussion, motivation to learn, work motivation, worship motivation, harmonious motivation, tolerance and a sense of responsibility in the family.

There are $92 \%$ having 10 to 14 types of needs from 14 types of social needs. Social needs include: feeling needed by others, being part of the group, feeling comfortable in society, feeling accepted by the surrounding community, to be known to others, appreciation from other people or friends, adjusting to community, 
recognition in society, values social in society, religious values in society, a sense of togetherness in society, tolerance in society, mutual respect for fellow friends, and the need for democracy.

There are $96 \%$ having 7 to 10 types of needs from 10 types of information needs. The need for information includes: the need for information about healthy living, information about rights and obligations as citizens, information on how to obtain and utilize government facilities, information on how to maintain public facilities, information about science for human life, information on how to use time well, information about family problems, information about the knowledge and meaning of community life, and information about how to respect others.

There are 91\% having 5 to 7 needs from 7 types of needs for the future. Future needs include: skills needs that can be used as provisions for working to make money, positive thinking for the future, freedom to develop themselves, provision of higher education, rational thinking learning, parental guidance, and guidance from leaders society.

As many as $83 \%$ have 8 to 10 needs from 10 types of needs with character. The need to behave in a character, moral and cultured includes: the needs of the values of religious life, exemplary figures in the family, exemplary figures in society, ways of tolerance, the environment around the local community that preserves local culture, moral education, moral guidance from parents, moral education that is easily understood, understands how to respect others, and how to have good democracy.

The results of this study basically have three categories of problematic children. The first category, personal problems, psychological, self-harm, not detrimental to others, and do not interfere with other parties, marked by daydreaming, aloof, crying; Second, social problems, social in nature, actually harm themselves, harm other parties or others, marked by nosy behavior disturbing friends, making noise, scribbling school walls as a sign of protest; Third, criminal problems, their behavior is illegal, marked by theft, fighting, violence, sexual abuse, rape and murder. The profile of problem children in this study belongs to the third category, namely: criminal behavior and breaking the law.

Stakeholders have a high commitment to implement Law No. 11 of 2012 concerning the Child Criminal Justice System, both for cases not yet included in the legal domain and for children who have become convicts. This is evidenced by the issuance of the Bengkulu Governor's Decree Number: D.54 / XXXI / Year 2016 dated February 9, 2016 concerning the Communication Forum on Handling Children Against Law in Bengkulu Province. This forum involved several agencies, each agency formulating service activities for children. The disadvantage is that there is still a low level of understanding regarding matters relating to children dealing with the law, lack of infrastructure and facilities, the absence of a Regional Regulation, the unavailability of special budget from the government.

\section{Discussion}

Troubled children who are discussed in research with criminal status. That is, they have been declared to have violated criminal law. The age of problem children is in early adolescence until late adolescence is in the process of seeking identity. Intellectually adolescents begin to be able to think logically about abstract ideas (Rumini \& Sundari, 2004), on the other hand adolescents experience peak emotionality, high level emotional development, show sensitivity, strong reactive, negative and temperamental emotions (Rumini \& Sundari, 2004). This condition results in an imbalance between the development of emotional thinking and development, which ultimately results in deviations from the law. Teenagers become aggressive and deviant behavior, among others: fighting, stubbornness, fighting, rape and even murder.

Adolescence can be categorized as a period of moral dilemma. Adolescence's insight into thinking is increasingly widespread, can include religion, justice, morality, and identity or identity (Yusuf \& Anak, 2007), with aggressive emotional development, running away from reality, daydreaming, quiet, happy to be alone, consuming tranquilizers, liquor , or drugs (Yusuf \& Anak, 2007). On the one hand, insight into thinking is increasingly widespread, including religious, moral and justice insights, but at the same time is in a position of irritability, irritability, daydreaming, solitude, because of its low assertiveness. Problem children as convicts generally manifest angry behavior. Anger is a feeling of annoyance that arises as a response to anxiety that is perceived as a threat (Safaria \& Saputra, 2009). Child's aggravation and anger lead to theft, rape, and murder, they are less able to manage emotions, do not know their emotions properly and motivate themselves positively. Emotional intelligence of students from the aspect of recognizing self-emotion, managing emotions themselves and motivating themselves in the selection of secondary schools is in the medium category (Undriani, Yusri, \& Sukmawati, 2015). Assertiveness is an ability to communicate what is desired, thought and felt by others but still maintains and respects the rights and feelings of others (Hapsari, 2007). 
When a child has difficulty communicating his thoughts and feelings can lead to the emergence of deviant behavior. Assertive behavior is important for adolescents, especially in terms of disclosing negative emotions, namely anger. With assertive behavior, adolescents can express emotions of anger naturally and have a positive impact on themselves and others who are the object of anger and can solve problems that cause anger in adolescents (Falentina \& Yulianti, 2012). The more assertive a teenager is. The more controlled the disclosure of his angry emotions, and vice versa the more assertive a teenager is, the more uncontrolled the disclosure of his angry emotions (Falentina \& Yulianti, 2012). The moral dilemma they experience is that they understand something good and bad, but have difficulty implementing the good and avoiding the bad. This confusion is that if teenagers are not in a harmonious family, a conducive community environment and bad peers, there will be deviant behavior that violates the law. The moral dilemma of children does not get guidance from parents optimally because of the role of parents who focus on their father's work in meeting basic family needs. Parents are less able to provide overall character education. Character education contains three main elements, namely knowing the good, loving the good, and doing the good (Dharmawan, 2014).

This condition makes their children feel free to do whatever they want. In terms of academic achievement in schools it was found that $88 \%$ of teens whose parents divorced experienced setbacks and tended to behave aggressively towards other students (Hines III, 2007). In cases of sexual abuse and rape it is also caused by the parents of those with low education who do not have sufficient understanding of their child's hormonal changes. Sexual education must be given in person, because the narrow scope of knowledge with the slow pace of developmental stages is not the same for every child. With a personal approach, the method and content of the description can be adjusted to the special situation of the child (Gunarsa, 2008).

Problem children are derived from the education level of their parents. This study proves the existence of linearity between the level of education of children with problems with the level of education of parents. The education level of parents is low, their children's education level also tends to be low. The level of education of parents and children has a low influence on the level of understanding of a problem, its actions are not considered, easily influenced by peer groups. Peer groups are the main reference source for adolescents in terms of perceptions and attitudes related to lifestyle (Papalia, Olds, \& Feldman, 2009).

Troubled children who live together with their parents, but their parents have the highest education graduating from junior high school and their fathers earn irregular income. The condition of parents like that is very hard to be able to provide good care to their children, so parents are not able to play a good role. Although with parents, but if the conditions are not harmonious, the child becomes aggressive. During the process of finding adolescent self-identity often adolescents experience pressure from parents regarding roles. The importance of the role of fathers in children's lives, shows that fathers have a significant role in fostering social-emotional, cognitive, language, and motor development (Scott \& De La Hunt, 2011). In socialemotional development it was found that, quality time between children and fathers can improve self esteem, self-confidence, social competence and life skills. Children who have a close relationship with their father have higher self esteem and are not easily depressed (Kamila \& Mukhlis, 2013).

Parents want their teenage children to play a role in helping increase income, on the other hand teenagers want to be independent. The pressures that arise from the environment and parents who want children to play an adult role, even though they are still classified in adolescence, the child is psychologically unable to deal with it. They are unable to deal with pressure. Locus of control is the result of an action that is influenced by skill or luck (external)(Feist \& Feist, 2010). Problem children who face the law do not have good external locus of control. They still have parental expectations from their parents. The involvement of fathers in parenting gives a positive impact and the bond between children and fathers gives its own color in the formation of children's character (Abdullah, 2009). Low-educated teenage children come from both loweducated parents and rarely harmonious social interactions make children troubled, and further have problems dealing with the law. One characteristic of broken-home families is the separation of husband and wife, they do not live at home. As a result, attention to children relies on each other, eventually children actually do not get the maximum education.

In the case of living with a father and mother, it turns out that their child has a problem, this is because their social interactions are less effective. Even though he lives with his father and mother, his father and mother are rarely at home, but gardening. In addition, it was also due to the education level of the father who turned out to be the most educated with the highest level of primary school education, as well as the education level of his mother. This means that the education level of the child's parents is one of the causes of problematic children. Related to the case, child convicts in cases of sexual abuse, rape, can occur because of the low level of education of parents. Sexual education in schools and especially in families must get attention. Family guidance programs, and marriage guidance can be carried out periodically by every organization of mothers and women's organizations in general. 
The results of this study indicate that problem children come from families that are less harmonious, their parents' work does not support family needs, the education level of their parents is classified as low, does not have a model figure in character building for the cultivation of moral values, communication is not good because rarely gather together. This means that they do not have role models in behaving. The modeling process begins with attentional processes, namely teens pay attention to models that are considered to attract their attention or have characteristics that are appropriate for adolescents, including in moral education (Yuliawati, Lukito Setiawan, \& Wijaya Mulya, 2007). Prisoners do not get the right model because they live in an environment where there are no role models. The lack of behavioral models that can be imitated by adolescents, it is only natural that adolescent behavior is also not good. Especially for adolescents who have a short way of thinking, there are not many moral considerations so that it is so easy to imitate the behavior of state leaders who actually do not support character education. Another finding in this study is that the needs of adolescents who are not well fulfilled are the needs of the future. Thinking they are not future-oriented, but are oriented now. Future orientation describes how individuals perceive themselves in the context of the future. This future orientation is related to expectations, standard goals, planning, and goal achievement strategies (Marliani, 2013). When children do not think about the future, they become short thinking, in behaving not much consideration.

Adolescent needs that are not met by families, peers, society and government proportionally, children become problematic. Harmonious interactions between children and parents must be intertwined. Interactions between children and fathers have an impact on social and moral development (Maccoby, 1980). Bad interactions can have negative children's behavior, negative cohesion. Family cohesion is based on the amount of time used by families to gather together, the quality of communication, and the involvement of adolescents in family decision making (Lian \& Yusooff, 2009).

The absence of parents in a family because a job can cause families to rarely gather in full, poor communication and adolescents are not involved in decisions. Children whose fathers were involved in parenting showed more ability in an internal control center, better ability to take initiative, self-control and fewer impulsivity, so children were able to control their actions against the outside world (Allen \& Daly, 2007). One of the psychological needs of adolescents is the need for self-eestem that is not fulfilled. The offense factor becomes a fight and even murder. Self esteem is a global evaluative dimension of oneself; as self-dignity or self-image (Santrock, 2007). Self-esteem of female adolescents declined among girls from 12 to 17 years old, while in adolescent boys it increased from the age of 12 to 14 years, then declined to the age of around 16 years before finally increasing again (Santrock, 2007). There are differences in self esteem between adolescents who have fathers and teens who do not have fathers. Groups of adolescents who have fathers have higher self esteem compared to groups of adolescents who do not have fathers (Kamila \& Mukhlis, 2013). Father has influence in several areas specifically on child development, one of which is father's teaching and encouraging freedom (Thomas, 2008).

Families, communities and the government are also responsible for education for problem children. Educating which emphasizes the development of moral honesty, is the main target of emotional intelligence of students, which must be accounted for by the teacher along with all components of the school(Suhartono \& Muhsin, 2007). Regarding the fulfillment of children's basic rights, various efforts to provide services must be carried out by families, communities and the government in synergy. Fulfillment of needs is influenced by individual factors (age and level of education), family factors (parents 'education level, parents' expectations, and type of work), environmental factors (exemplary in society, community acceptance, customs, education services in schools, environmental facilities and government care). Meeting the needs of problem children can be done through an appropriate educational model. There were four models to instill moral values of human life as personal, intelligent, and cultured beings, namely: models as separate subjects, integrated models in all fields of study, models outside of teaching, and combined models(Suparno, 2003).

\section{Conclusion}

Children with problems until dealing with the law are experienced by those who are in adolescence, have low education so that they are unable to comprehend the problem wisely and lack careful consideration, coming from parents with low education. They are in a disharmonious family so they are not able to meet the needs of adolescents proportionally and in the community do not care about the needs of adolescents.

To realize the quality of moral and character of life, it is suggested to the government to provide an institutionalized and sustainable education model that involves the active role of all components of society based on the analysis of adolescent needs. 


\section{Acknowledgment}

Acknowledge anyone who has helped you with the study, including: Researchers who supplied materials, reagents, or computer programs; anyone who helped with the writing or English, or offered critical comments about the content, or anyone who provided technical help.

State why people have been acknowledged and ask their permission. Acknowledge sources of funding, including any grant or reference numbers. Please avoid apologize for doing a poor job of presenting the manuscript.

\section{References}

Abdullah, S. M. (2009). Keterlibatan ayah dalam pengasuhan anak (paternal involvement): sebuah tinjauan teoritis. Universitas Mercubuana Yogyakarta.

Allen, S. M., \& Daly, K. J. (2007). The effects of father involvement: An updated research summary of the evidence. Centre for Families, Work \& Well-Being, University of Guelph.

Dharmawan, N. S. (2014). Implementasi pendidikan karakter bangsa Pada mahasiswa di perguruan tinggi. Makalah Dipresentasikan Pada Pembinaan Pendidikan Karakter Bagi Mahasiswa PTS Di Lingkungan Kopertis Wilayah VIII, Universitas Udayana Denpasar.

Falentina, F. O., \& Yulianti, A. (2012). Asertivitas terhadap pengungkapan emosi marah pada remaja. Jurnal Psikologi, 8(1), 9-14.

Feist, J., \& Feist, G. J. (2010). Teori Kepribadian: Theories Of Personality, terj. Smita Prathita Sjahputri,(Jakarta: Salemba Humanika, 2009).

Gunarsa, S. D. (2008). Psikologi perkembangan anak dan remaja. BPK Gunung Mulia.

Hadiwinarto, H. (2018). URGENSI KONSELING SPIRITUAL. JURNAL BIMBINGAN DAN KONSELING AR-RAHMAN, 4(2), 40-46.

Hamid, A., \& Sudira, P. (2013). Penanaman nilai-nilai karakter siswa smk salafiyah prodi tkj kajen margoyoso pati jawa tengah. Jurnal Pendidikan Vokasi, 3(2).

Hapsari, R. M. (2007). Sumbangan Perilaku Asertif Terhadap Harga Diri Pada Karyawan. Jurnal Penelitian Psikologi, 1(1).

Hines III, M. T. (2007). Adolescent adjustment to the middle school transition: The intersection of divorce and gender in review. RMLE Online, 31(2), 1-15.

Kamila, I. I., \& Mukhlis, M. (2013). Perbedaan Harga Diri (Self Esteem) Remaja Ditinjau dari Keberadaan Ayah. Jurnal Psikologi, 9(2), 100-112.

Kartadinata, S. (2013). Mencari Bentuk Pendidikan Karakter Bangsa. Makalah. Fakultas Ilmu Pendidikan. Universitas Pendidikan Indonesia. Bandung. Http://file. Upi. Edu/direktori/fip/jur. _psikologi_pend_dan_bimbingan/195, 32119.

Kartono, K. (2011). Patologi Sosial 2 Kenakalan Remaja cetakan ke-10. Jakarta: PT. Raja Grapindo Persada.

Lian, T. C., \& Yusooff, F. (2009). The effects of family functioning on self-esteem of children. European Journal of Social Sciences, $9(4), 643-650$.

Maccoby, E. E. (1980). Social development: Psychological growth and the parent-child relationship. New York: Harcourt Brace Jovanovich.

Marliani, R. (2013). Hubungan antara religiusitas dengan orientasi masa depan bidang pekerjaan pada mahasiswa tingkat akhir. Jurnal Psikologi, 9(2), 130-137.

Murtadlo, A. (2009). Pendekatan Nilai: Kajian atas Implementasi Pendidikan Budi Pekerti dalam Proses Pembelajaran. Innovatio, $8(1)$.

Nomor, U.-U. R. I. (11AD). Tahun 2012 tentang Sistem Peradilan Pidana Anak. Lembaran Negara Republik Indonesia Nomor, 153.

Papalia, D. E., Olds, S. W., \& Feldman, R. D. (2009). Human Development (Perkembangan manusia edisi 10 buku 2). Jakarta: Salemba Humanika.

Rahmaningsih, N. D., \& Martani, W. (2014). Dinamika konsep diri pada remaja perempuan pembaca teenlit. 
Jurnal Psikologi, 41(2), 179-189.

Rumini, S., \& Sundari, S. (2004). Perkembangan anak dan remaja. Jakarta: Rineka Cipta.

Safaria, T., \& Saputra, N. E. (2009). Manajemen Emosi: Sebuah panduan cerdas bagaimana mengelola emosi positif dalam hidup anda. Jakarta: Bumi Aksara.

Santrock, J. W. (2007). Remaja, edisi kesebelas. Jakarta: Erlangga.

Scott, W., \& De La Hunt, A. (2011). The important role of fathers in the lives of young children. Parents as Teachers.

Soekanto, S. (2012). Sosiologi Suatu Pengantar Cetakan ke-44. Jakarta: PT Raja Grafindo Persada.

Suhartono, S., \& Muhsin, I. (2007). Filsafat pendidikan. Ar-Ruzz Media.

Suparno, P. (2003). Pendidikan budi pekerti: untuk SMU-SMK. Kanisius.

Suyadi. (2013). Strategi pembelajaran pendidikan karakter: PT Remaja Rosdakarya.

Suyatno, H. (n.d.). PERAN PENDIDIKAN SEBAGAI MODAL UTAMA MEMBANGUN KARAKTER BANGSA.

Thomas, D. (2008). Paternal involvement in pre-school readiness. Humboldt State University.

Undriani, Y., Yusri, Y., \& Sukmawati, I. (2015). Kecerdasan Emosional Siswa dalam Pemilihan Sekolah Lanjutan. Konselor, 4(2), 102-110.

Walgito, B. (2000). Bimbingan dan Konseling (Studi dan karier): Penerbit Andi. Yogyakarta.

Yuliawati, L., Lukito Setiawan, J., \& Wijaya Mulya, T. (2007). Perbedaan Kecerdasan Emosional Remaja Ditinjau Dari Keberadaan Ayah The Difference In Adolescent Emotional Intelligence From The Perpective Of The Existence Of Father.

Yusuf, S., \& Anak, P. P. (2007). Remaja. Bandung: PT. Remaja Rosdakarya. 